\title{
Impact of the Great Earthquake-2015 on Hospitality Industry of Nepal
}

\author{
Sushant Tuladhar*
}

\begin{abstract}
Hospitality organizations face a serious threat from disasters, with only few of these firms engaged in planning for effective disaster management. Nepal has a high risk profile for natural disasters; and it was struck by the great earthquake on April 25 ${ }^{\text {th }}, 2015$ which was followed by 400-plus aftershocks creating havoc mostly in the eastern, central and western part of the country. This article aims to present some insight on the impact of the earthquake in the hospitality sector. Secondary data available from various reports, newspaper articles, government reports, and studies conducted by individuals and different organizations have been taken into account while preparing this article. Some people associated with hotels of different category from different locations were also interviewed to get in-depth views on the effects of the natural calamity. The damages and losses caused by the earthquake have engulfed most of the tourismrelated organizations and activities. This has subsequently made the concerned stakeholders - regardless of their size and scope of operation - to rethink about their strategy for disaster preparedness. After studying the extent of the same, all hospitality firms are encouraged to prioritize the need and to engage in practice for disaster and crisis management.
\end{abstract}

Keywords: Earthquake, Nepal, hotel industry, disaster preparedness

\section{Introduction}

Worldwide, the hospitality industry is facing increasing rates of disasters resulting from both naturally occurring disasters, such as the 2010 earthquake devastation in Haiti or the 2011 tsunami in Japan, and man-made disasters such as terrorist attacks in the likes of 2008 attack on the hotels in Mumbai, India and the September $11^{\text {th }}$, 2001 terrorist attacks in the United States. British security personnel, as well as hospitality industry leaders, faced monumental security challenges in their successful efforts to avoid any major crisis situations or disasters during the 2012 Summer Olympics. While many disasters occur either locally or regionally, their impacts are

\footnotetext{
* Sushant Tuladhar has completed his Master Degree in Innovation and Management in Tourism from International School of Tourism and Hotel Management (IST), Kathmandu, affiliated to Salzburg University of Applied Sciences (FHS), Austria. He is a full time faculty at IST as Deputy Manager - F\&B Operation.
} 
often felt over a much larger region than that in which the disaster occurred and may even be felt on a global scale; thus, magnifying the importance of the hospitality industry's ability to manage and recover from disaster situations. Similarly, many hospitality firms recognize that disaster planning is important; however such planning is still too often a neglected part of a firm's management actions. As a result, many hospitality firms are still at a low level of disaster preparedness (Gruman, Chhinzer \& Smith, 2011; McCool, 2012; Racheria \& Hu, 2009; Soraghan, 2009).

\section{Natural Disasters and Tourism}

Natural disasters are a basic part of the workings of nature and therefore, will always be with human beings and other species. Nature forces occur just about everywhere, from rural towns to metropolitan cities. It is difficult for mankind to escape contact with natural forces because the human population continues to grow. Therefore there are increasing numbers of people who are forced to inhabit areas susceptible to disasters. Natural forces do not discriminate in terms of where they strike and how much destruction they cause. Each one is powerful in its own right. With all of the human technology that exists today, scientists are only able to monitor conditions in an attempt to predict the occurrence of natural forces and its intensity. The violent forces of nature have been part of this world long before the arrival of mankind. These forces helped shape the history of the world and, are nature's way of retaining balance and stability (Beattie, 1992).

Kendrick Frazier (1979) stated in his book, The Violent Face of Nature - Severe Phenomena and Natural Disasters, that the powerful forces of nature are not something apart from the natural order of things. They are the natural consequences of a quest for balance, an outgrowth of the need for equilibrium. With the arrival of mankind, natural forces became natural 'disasters' because they began to disrupt the lives of people. Natural forces that take place in uninhabited areas are not disasters. They are in fact just nature's way of maintaining stability. It takes both the presence of humans and a natural force to make a disaster.

When a natural force strikes an area populated by the people and developed with real estate and businesses, it becomes a disaster because there is the potential for great loss in terms of lives and property. Natural disasters are catastrophic events that are likely to outstrip the capacity of societies to manage their impacts (Richardson, March, Lewis \& Radel, 2012). While such events are usually limited in their duration, they are nevertheless events on a scale sufficiently significant to cause governments to substantially and often urgently modify their funding and political priorities. The events can have sizeable and long-term negative impacts on the social, economic and ecological environment in the affected areas (Anderson, 1990).

There has been an increasing trend in the communicated cost of natural disasters globally (Munich Re, 1999) and recovery from these disasters can account for a 
significant proportion of national economies (Benson \& Clay, 2004; Munich Re, 1999). Direct losses include damage to premises, infrastructure, equipment and loss of revenue resulting directly from the event (Cochrane, 2004). Indirect losses, which are difficult to measure, include income loss due to supply chain issues or decreased sales caused by customer income losses (National Research Council, 1999). Rose and Lim (2002) state that business interruption losses are possible even without physical or property damage and can result from interdependencies and flow-on effects between organizations, employees, suppliers and customers. Also, the trajectory of economic trends within business sectors is influenced by disasters (Benson \& Clay, 2003). For instance, it is expected that the retail sector suffers loss of revenue while the construction and manufacturing sectors experience a boom in the wake of a disaster (Boarnet, 1997; Tierney \& Webb, 2007). It is recognized that factors such as the type of organization and industry sector, the size of the organization and its location contribute to how different organizations and sectors recover from disaster (Kachali et al, 2012).

Tourism is a major sector of the world economy. Shorter working hours, greater individual prosperity, faster and less expensive travel, and the impact of advanced technology has all helped to make the leisure and tourism industry the fastest growing industry in the world. (Edgell, Sr., 1990). Regardless of their reasons for traveling, tourists spend money. Travel and tourism generated US\$7.6 trillion (10\% of global GDP) and 277 million jobs ( 1 in 11 jobs) for the global economy in 2014. Recent years have seen travel \& tourism growing at a faster rate than both the wider economy and other significant sectors such as automotive, financial services and health care. International tourist arrivals also have surged, reaching nearly 1.14 billion and visitor spending more than matched that growth. Visitors from emerging economies represented a $46 \%$ share of these international arrivals (up from 38\% in 2000), proving the growth and increased opportunities for travel from those in these new markets (WTTC, 2015).

In this scenario, natural disasters and tourism are two elements that play significant roles in the world today and will continue in the future. In the past these two elements have intersected and it is likely that they will again in the future (Beattie, 1992).

Separately, natural disasters and tourism conjure up entirely different images. When thinking of tourism, images that come to mind are vacationers, fun, relaxation, sightseeing and beautiful surroundings. Natural disasters, on the other hand, bring to mind images of destruction, death and tragedy. For many people, areas affected by natural disasters do not conjure up images of ideal vacation destinations. It appears that these two elements are on opposite ends of the spectrum and therefore, are mutually exclusive rather than complementary. Often it seems that tourism and the benefits derived from it become 'victims' of natural disasters (Beattie, 1992). 


\section{Natural Disasters in Nepal}

Nepal, officially known as the Federal Democratic Republic of Nepal, is a landlocked sovereign country located in South Asia. It has an area of 147,181 square kilometers and a population of approximately 27 million. It is located in the Himalayas and bordered to the north by the People's Republic of China, and to the south, east, and west by the Republic of India. Kathmandu is the capital of the country and the most populous city of the country (CBS, 2010).

Nepal is situated on the southern slopes of the Central Himalaya. The country is located between latitudes $26^{\circ} 22^{\prime}$ and $30^{\circ} 27^{\prime} \mathrm{N}$, and longitudes $80^{\circ} 40^{\prime}$ and $88^{\circ} 12^{\prime} \mathrm{E}$. The length of the country is $885 \mathrm{~km}$ from west to east and its width varies from $145 \mathrm{~km}$ to $241 \mathrm{~km}$ with a mean of $193 \mathrm{~km}$ north-south. About $86 \%$ of the total land area is covered by hills and high mountains, and the remaining $14 \%$ are the flat lands of the Terai region with less than $300 \mathrm{~m}$ in elevation. Altitude varies from some $67 \mathrm{~m}$ above sea level at Kechana Kalan, Jhapa district in the south-eastern Terai, to 8848 meters at the peak of the world's highest mountain Mt Everest, or known as Sagarmatha amongst Nepalese (CBS, 2010).

With its unique geo-physical settings and socio-economic conditions, Nepal is highly vulnerable to disasters. The country is prone to disasters due to a number of factors, both natural and human-induced, including adverse geo-climatic conditions, topographic features, environmental degradation, population growth, urbanization, unsuitable development practices, and so on. As far as the geographic dimension of the country is concerned, five ecological regions of the country exhibit their own specific problems. Due to geographical and other climatic conditions, rugged and steep topography, extreme weather events and fragile geological conditions, the country is regarded as a disaster hotspot because of vulnerability of the population together with regular and frequent occurrences of different natural hazards (MoHA \& DPNetNepal, 2013).

\section{Risk Profile of Nepal}

Located in the central of the Himalaya range, Nepal is one of the most disaster prone countries in the world due to its topography and climatic condition. Earthquakes, landslides, floods, fire, thunderbolts are the major causes of disaster events that caused major damaged in the past, weakening the fragile ecosystem of the country. Economic Vulnerability Analysis shows that Nepal exhibits the largest losses due to large exposure at risk and the high level of hazards. As a matter of these phenomena not only cause loss of lives and properties, but also pose severe threats to physical infrastructure, and also disrupt economic development (Nepal Disaster Risk Reduction Portal, 2015a). 
The frequently occurring natural disasters and likely zones are mentioned below: Landslide

Landslide is one of the very common natural hazards in the hilly region of Nepal. Both natural and human factors such as steep slopes, fragile geology, high intensity of rainfall, deforestation, unplanned human settlements are the major causes of landslide. The risk of landslide is further exacerbated by anthropogenic activities like improper land use, encroachment into vulnerable land slopes and unplanned development activities such as construction of roads and irrigation canals without proper protection measures in the vulnerable mountain belt. The hilly districts of Nepal located in the Siwalik, Mahabharat range, Mid-land, and also fore and higher Himalayas are more susceptible to landslide because of steep topography and fragile ecosystem.

\section{Floods}

Flood is a common cause of flood in the rainy season in Nepal, and has been most frequent, highly damaging and wide spread natural hazards. It is estimated that more than 6,000 rivers and rivulets are in Nepal flowing from north to south. Among these, snow fed rivers, such as the Koshi, Narayani, Karnali, and Mahakali, are perennial rivers. They originate from the Himalayas and snow capped mountains and pass through the hills to the Terai plains. During the monsoon (June-September), these rivers swell and cause damage to the villages, crops lands, and people and livestock remained within the river basins. Historical data has shown that Nepal witnessed major flood in Tinao basin (1978), Koshi River (1980), Tadi River Basin (1985), Sunkoshi Basin (1987) and devastating cloud burst in Kulekhani area (1993) which alone claimed the lives of 1336 people.

Glacial Lake Outburst Floods (GLOFs)

Glacial lakes are located in the high altitude areas particularly in the foot hill of mountain. The lakes are formed due to damming in by moraines. These lakes contained huge volumes of water melting of glacier may lead to outbreak the lakes, called a glacial lake outburst flood (GLOF) with substantial capacity to cause great damage in downstream. 2,315 glacial lakes have, in total, been identified in Nepal and 14 GLOFs were recorded to have occurred between 1935 and 1991 in Nepal. At this background, 15 glacial lakes are found substantially dangerous in Nepal.

Earthquake

Nepal on a regular interval witnesses earthquake along the major active faults in east-west alignment. Historical data and ongoing seismological studies have clearly indicated that the entire region of Nepal is prone to earthquake and it lies in the active seismic zone V. It is evident that the seismic pattern has geographically divided into three clusters of events; namely western, central and eastern Nepal. It has also pointed out that Siwalik, lesser Himalaya and frontal part of the Higher Himalaya are the most 
vulnerable zones. Historical data has shown that the country witnessed three major earthquakes in 20th century namely Bihar-Nepal earthquake (1934), Bajhang earthquake (1980) and Udayapur earthquake (1988). According to Global Report on Disaster Risk, Nepal ranks in $11^{\text {th }}$ position in terms of earthquake risk as earthquakes have often occurred in Nepal.

Fire

Of the total households of the country, nearly 78 percent households are agrobase households. In the rural areas thus, about 86 percent of the population lives in the houses made of earthen wire, stone and wood. In Nepal, houses for residential purpose are developed in cluster basis which are more susceptible to catching fire and spreading over there immediately due to close connectivity especially in the dry season. Wildfire is another cause of natural disaster which usually occurs during dry season, especially in the mid hill areas. In the Terai region, fire, including the wildfire occurs mainly in the dry season.

\section{Drought}

Drought is the frequently happening hazard in Nepal. This is mainly caused by uneven and irregular low monsoon rainfall. Some parts of Terai, mid-land and TransHimalayan belts of Nepal are prone to drought. The lack of irrigation facilities further exacerbates the effect of drought causing enormous loss of crops production leading to the shortage and insecurity food. The droughts that happened in 1972 and 1979 were the most seriously damaging and harmful to the people, livestock and crops. In 1994 Nepal witnessed the worst drought in its history that affected 35 districts of western hilly and Terai regions.

\section{Avalanche}

Avalanches are a rapid movement of snow and debris flowing down through the slope or flanks of mountains. It can be triggered by natural factors like slopes, thickness of snow or human activity. They have the capacity to carry massive masses of snow and associated debris that make them one of the most destructive elements of hazards. The high mountainous region having the rugged and steep slopes topographically is susceptible to avalanche. A number of cases of avalanche with destructive nature have been reported in Nepal. Unexpected Seti River Flood of $5^{\text {th }}$ may, 2012 at Kaski district could be an example of this type of hazard.

\section{Tourism in Nepal}

The country profile published by WTTC in 2015 provides details on the performance of tourism sector in Nepal. As per the report, the direct contribution of 'travel and tourism' sector to GDP (Gross Domestic Product) was NPR 83.7 billion (4.3\% of total GDP) in 2014 , and is forecast to rise by $5.4 \%$ in 2015 , and to rise by $4.4 \%$ per annum, from 2015-2025, to NPR 135.7 billion (4.8\% of total GDP) in 2025. Likewise, the total 
contribution of travel and tourism to GDP was NPR 171.6 billion (8.9\% of GDP) in 2014 , and is forecast to rise by $5.8 \%$ in 2015 , and to rise by $4.5 \%$ per annum to NPR 281.5 billion (10.0\% of GDP) in 2025.

Similarly, in 2014 , travel and tourism directly supported 487,500 jobs $(3.5 \%$ of total employment). This is expected to rise by $4.0 \%$ in 2015 , and rise by $3.0 \%$ per annum to 681,000 jobs (3.9\% of total employment) in 2025 . The total contribution of travel and tourism to employment, including jobs indirectly supported by the industry, was $7.5 \%$ of total employment $(1,059,000$ jobs). This is expected to rise by $4.4 \%$ in 2015 to $1,105,000$ jobs, and rise by $3.1 \%$ per annum to $1,494,000$ jobs in 2025 , or $8.5 \%$ of the total (WTTC, 2015).

Visitor exports generated NPR 53.7 billion (25.2\% of total exports) in 2014. This is forecast to grow by $1.1 \%$ in 2015 , and grow by $6.0 \%$ per annum, from $2015-2025$, to NPR 97.3 billion in 2025 (23.8\% of total). Travel and tourism sector investment in 2014 was NPR 15.7 billion, or 3.6\% of total investment. It is estimated to rise by $12.0 \%$ in 2015 , and rise by $5.2 \%$ per annum over the next ten years to NPR 29.2 billion in 2025 (4.6\% of total) (WTTC, 2015).

The number of tourists visiting Nepal has been targeted to reach 2 million by the year 2020. February, March and April in spring season, and September, October and November in autumn season are deemed to be the most appropriate time to visit Nepal; and it receives the maximum number of its guests in the afore-mentioned months. Monthly tourist arrivals in the years 2013 and 2014 are shown in the table below:

Table 1: Tourist Arrivals by Month in 2013 \& 2014

\begin{tabular}{|c|c|c|c|c|c|c|c|c|c|c|c|c|c|}
\hline \multirow{2}{*}{ Year } & \multicolumn{10}{|c|}{ Month } & \multirow{2}{*}{ Total } \\
\cline { 2 - 12 } & Jan & Feb & Mar & Apr & May & Jun & Jul & Aug & Sep & Oct & Nov & Dec & \\
\hline 2013 & 47,846 & 67,264 & 88,697 & 65,152 & 52,834 & 54,599 & 54,011 & 68,478 & 66,755 & 99,426 & 75,485 & 57,069 & 797,616 \\
\hline 2014 & 70,196 & 69,009 & 79,914 & 80,053 & 62,558 & 50,731 & 46,546 & 59,761 & 52,894 & 80,993 & 76,305 & 61,158 & 790,118 \\
\hline
\end{tabular}

Source: MOCTCA, 2015: 33

Similarly, tourism is one of the main contributors of foreign currency income in Nepal's economy. As per the reports published by Ministry of Culture, Tourism and Civil Aviation (MOCTCA, 2015), Nepal generated NPR 46 billion in foreign exchange earnings in the fiscal year 2013/14, a $21.4 \%$ rise in comparison to the previous year, as shown in Table 2. Each visitor had spent on average US\$ 48 daily in 2013/14, compared to US\$ 42.8 in 2012/13. This data highlights an increasing trend in tourism earnings. The first eight months of the current fiscal year, from July 2014 to February 2015, did generate NPR 34 billion. The details on the same after the great earthquake in April 2015 are yet to be published. 
Table 2: Gross Foreign Exchange Earnings from Tourism

\begin{tabular}{|c|c|c|c|c|c|c|}
\hline \multirow[b]{2}{*}{$\begin{array}{c}\text { Fiscal } \\
\text { Year }\end{array}$} & \multicolumn{3}{|c|}{ Total Earnings (Net received) } & \multirow[b]{2}{*}{\begin{tabular}{l}
\multicolumn{1}{c}{$\%$} \\
Change \\
in US\$
\end{tabular}} & \multirow{2}{*}{$\begin{array}{c}\text { Average } \\
\text { expenditure } \\
\text { per visitor } \\
(\mathrm{US} \$)^{\star}\end{array}$} & \multirow{2}{*}{$\begin{array}{c}\text { Average } \\
\text { expenditure } \\
\text { per visitor } \\
\text { per day } \\
\text { (US\$) }\end{array}$} \\
\hline & NPR (000) & $\begin{array}{c}\text { Annual } \\
\text { average } \\
\text { exchange } \\
\text { rate }\end{array}$ & US\$ (000) & & & \\
\hline $2012 / 13$ & $34,210,576$ & \begin{tabular}{|l|}
87.66 \\
\end{tabular} & 390,264 & 2.6 & 538 & 42.8 \\
\hline $2013 / 14$ & $46,374,900$ & 98.3 & 471,769 & 21.4 & 597.6 & 48.0 \\
\hline $2014 / 15^{\star}$ & $34,313,300$ & 98.6 & 348,005 & 13.6 & NA & NA \\
\hline
\end{tabular}

Source: MOCTCA, 2015: $71 \& 74$

\section{Nepal's ranking in Global Tourism}

In 2014, out of 184 countries affiliated to World Travel and Tourism Council, Nepal ranked in $122^{\text {nd }}$ position in terms of absolute relative importance of travel and tourism's total contribution to GDP. Likewise, it ranked $101^{\text {st }}$ in terms of relative size of contribution to GDP. Nepal is forecast to be $26^{\text {th }}$ nation relative to the growth of travel and tourism sector, while it ranked $72^{\text {nd }}$ in terms of long-term (2015-2025) growth estimate (WTTC, 2015).

\section{Hotels in Nepal}

The number of star hotels that stood at 117 between the periods of mid-January 2013 and mid-January 2014 had reached to 118 by mid-January 2015 with addition of one hotel during the same. The number of tourist class hotels except star hotels increased to 957 by mid-January 2015 from 909 of the previous year. Similarly, the number of beds in star hotels reached to 9,554 with increase of 48 beds as compared to preceding year, while the number of beds in tourist class hotels other than the star hotels increased by 1,608 reaching a total of 26,625 by mid-January 2015 (Ministry of Finance, 2015: 157).

Table 3: Contribution to GDP by Hotels and Restaurants

\begin{tabular}{|l|l|l|l|l|}
\hline \multicolumn{1}{|c|}{ Fiscal Year } & $\mathbf{2 0 1 2 / 1 3}$ & $\mathbf{2 0 1 3 / 1 4 R}$ & $\mathbf{2 0 1 4 / 1 5 P}$ & $\mathbf{2 0 1 4 / 1 5 P *}$ \\
\hline Gross Output (NPR millions) & 95,080 & $1,08,943$ & $1,23,683$ & $1,20,639$ \\
\hline Gross Output at basic prices & $2,525,886$ & $2,857,120$ & $3,146,376$ & $3,094,883$ \\
\hline $\begin{array}{l}\text { Contribution to Gross Domestic } \\
\text { Product in percentage }\end{array}$ & 1.89 & 1.96 & 2.09 & 2.07 \\
\hline $\begin{array}{l}\text { Annual Growth Rate of GDP in } \\
\text { percentage }\end{array}$ & 5.50 & 6.77 & 6.60 & 3.98 \\
\hline Overall Annual GDP Growth & 4.13 & 5.38 & 5.00 & 3.36 \\
\hline R = Revised; P = Preliminary; $\mathrm{P}^{*}=$ Preliminary revised after earthquake \\
\hline
\end{tabular}

Source: CBS, 2015: 315, 325 \& 326 
Central Bureau of Statistics (CBS) publishes National Accounts every year with respect to Gross Domestic Product (GDP) of the nation and contribution to it by different sectors of the country. The table above, Table 3, shows the contribution of Hotels and Restaurants sector to the GDP of Nepal. The data provided for the fiscal year 2012/2013 and 2013/14 are actual figures, whereas the estimated figures for the fiscal year 2014/15 have been revised after the great earthquake. Based on the increasing trend of tourism activities and number of tourists in 2014, it had been estimated that this sector would experience a growth of $6.60 \%$, compared to the nation's overall GDP growth rate of $5 \%$. However, the aftermath of the earthquake has forced the growth rate to be estimated at 3.98\%; while that of the nation's overall annual GDP growth rate has been revised to $3.36 \%$, instead of the initial forecast of $5 \%$ in $2014 / 15$. The report shows that Nepal experienced a growth rate of 5.38\% in 2013/14, a improved one over the fiscal year 2012/13. It could be foreseen that decrease in economic activities have been expected after the earthquake.

\section{Impacts of Earthquake-2015}

Nepal is the $11^{\text {th }}$ most earthquake-prone country in the world. Ever since the first recorded earthquake of $1255 \mathrm{AD}$ that killed one-third of the population of the Kathmandu Valley and its King, Abhaya Malla, Nepal has experienced a major earthquake every few generations. The last great earthquake of magnitude 8.4 in 1934 $\mathrm{AD}$ resulted in more than 10,000 deaths in the Kathmandu Valley. Most of the infrastructure and major heritage sites had to be rebuilt. There have since been earthquakes causing severe human and physical loss in 1980, 1988 and 2011 (NPC, 2015a).

On Saturday, April 25 $5^{\text {th }}, 2015$ at 11:56 local time, a 7.6 magnitude earthquake as recorded by Nepal's National Seismological Centre (NSC), struck Barpak in the historic district of Gorkha, about $76 \mathrm{~km}$ northwest of Kathmandu. Nepal had not faced a natural shock of comparable magnitude for over 80 years.

The catastrophic earthquake was followed by more than 400 aftershocks greater than magnitude 4.0 (as of October 2015 as per National Seismological Centre). Four aftershocks were greater than magnitude 6.0, including one measuring 6.8 which struck 17 days after the first big one with the epicenter near Mount Everest. To date, there have been over 8,790 casualties and 22,300 injuries. It is estimated that the lives of eight million people, almost one-third of the population of Nepal, have been impacted by these earthquakes. Thirty-one of the country's 75 districts have been affected, out of which 14 were declared 'crisis-hit' for the purpose of prioritizing rescue and relief operations; another 17 neighboring districts are partially affected.

The destruction was widespread covering residential and government buildings, heritage sites, schools and health posts, rural roads, bridges, water supply systems, agricultural land, trekking routes, hydropower plants and sports facilities. Rural areas 
in the central and western regions were particularly devastated and further isolated due to road damage and obstructions. In the worst hit areas, entire settlements, including popular tourist destinations like Langtang, were swept away by landslides and avalanches triggered by the earthquakes. Due to the weakened, ruptured, and destabilized slopes and surfaces, the vulnerable areas have now become even more susceptible to flooding and landslides that could have occurred during the monsoon.

Hundreds of historical and cultural monuments at least a century old were either destroyed or extensively damaged. Over half a million houses were destroyed. The damage exposed the weaknesses of houses that did not have any seismic-resistant features or were not in accordance with the building codes. The disaster also highlighted aspects of inequities in Nepali society spanning geography, income and gender. Poorer rural areas have been more adversely affected than towns and cities due to their inferior quality of houses. More women and girls died than men and boys, partly because of gendered roles that disproportionately assign indoor chores to women.

The time and day the first earthquake was experienced saved thousands of lives. Being a Saturday, the weekly holiday, schools across Nepal were closed on 25 April. The death toll of young people could have been much higher considering that nearly 7,000 schools were completely or significantly damaged. Similarly, if the earthquake had struck at night, and not in the middle of the day, there would certainly have been greater casualties.

In services, tourism has been adversely affected with every nine in ten planned foreign arrivals cancelled in the aftermath of the quakes which occurred during the first of the two major seasons of the year. The main earthquake and prolonged aftershocks caused damage to seven out of 10 World Heritage sites in the Kathmandu Valley and affected popular trekking routes. Destroyed tourism-related supply of services and decreased tourist spending are likely to lead to a loss of NPR 62 billion over the next two years. Conditional on low or no seismic activity over the coming months, tourism is expected to rebound somewhat by the autumn, and strongly by next spring's climbing season.

\section{Cultural Heritage - Damages and Losses}

The earthquake affected about 2,900 structures with a cultural and religious heritage value. The list of damaged or destroyed structures was compiled by Ministry of Culture, Tourism and Civil Aviation (MOCTCA), the Pashupati Area Development Trust (PADT), and the Buddhist Philosophy Promotion and Monastery Development Committee. Major monuments in Kathmandu's seven World Heritage Monument Zones were severely damaged and many collapsed completely. In addition, in more than 20 districts, thousands of private residences built on traditional lines, historic public buildings as well as ancient and recently built temples and monasteries were affected by the earthquakes, 25 percent of which were destroyed completely. The total 
damage to tangible heritage is estimated to be at NPR 16.9 billion (US\$ 169 million) (NPC, 2015b).

The baseline information on the size and nature of damage to the buildings, and the effects on its occupants, varies widely. While detailed documentation is available on monuments within the Kathmandu Valley and some major sites in the districts, there is a lack of precise information on the condition of buildings in remote areas. It is estimated that the decline in revenue from ticket sales at monuments within the Kathmandu Valley will amount to losses worth NPR 600 million (US\$ 6 million) over the next 12 months. Places of worship such as temples and monasteries also provide occasions for revenue generation, such as during religious festivals and performances when shrines receive substantial monetary offerings. The preliminary monetary loss was set at 10 percent of the physical damage or close to US\$ 17 million (NPC, 2015b).

Table 4: Summary of Damages and Losses of Cultural Heritage

\begin{tabular}{|l|r|r|r|r|r|}
\hline \multicolumn{1}{|c|}{ Subsector } & \multicolumn{3}{|c|}{$\begin{array}{c}\text { Disaster Effects } \\
\text { (NPR Million) }\end{array}$} & \multicolumn{2}{c|}{$\begin{array}{c}\text { Share of Disaster } \\
\text { Effects }\end{array}$} \\
\hline & Damages & Losses & Total & $\begin{array}{c}\text { Private/ } \\
\text { Community }\end{array}$ & Public \\
\hline Heritages sites in 16 districts & 7,875 & 1,409 & 9,284 & - & 9,284 \\
\hline $\begin{array}{l}\text { Monasteries \& historic } \\
\text { structures (older than 100 years) }\end{array}$ & 5,300 & 530 & 5,830 & 5,830 & - \\
\hline $\begin{array}{l}\text { Monasteries \& historic } \\
\text { structures (less than 100 years) }\end{array}$ & 2,835 & 283 & 3,118 & 3,118 & - \\
\hline Temples in remote areas & 900 & 90 & 990 & & 990 \\
\hline Total & \multicolumn{16}{|c|}{} & & & & $\mathbf{8 , 9 4 8}$ & $\mathbf{1 0 , 2 7 4}$ \\
\hline${ }^{\star}$ Almost all the monasteries are under community ownership and management \\
\hline
\end{tabular}

Source: NPC, 2015b

\section{Cultural Heritage - Recovery Needs}

The cost of reconstruction has been calculated at the estimated value of damages plus 20 percent to build back better through the use of high quality building materials and structural improvements for seismic strengthening. The cost of recovery includes the professional services provided by technical experts, capacity building support to the Department of Archaeology (DoA), and support to the preservation of intangible cultural heritage $(\mathrm{ICH})$ by means of specialized training for craftspeople, among others.

It is estimated that the overall cost for recovery needs in all sectors after the great earthquake is NPR 669,505 million or US\$6,695 million. The amount forecast for recovering cultural heritage is calculated at NPR 20,553 million or US\$206 million. This represents a share of $3.1 \%$ of the overall amount (NPC, 2015b). 


\section{Tourism - Damages and Losses}

The overall impact of the earthquake on the tourism sector goes beyond the 14 affected districts, which have suffered significant physical damage to well-known tourism destinations like Chitwan and Pokhara in terms of a sharp fall in the number of tourists. The negative repercussions of the disaster are likely to be translated into a reduced number of tourist arrivals over the next few years, reduction in tourist spending per day from US\$43 to US\$35 (as per industry sources), which would significantly affect revenues. Other nations that have experienced similar disasters have generally taken several years to recover fully with regard to tourist arrivals. It is estimated that the overall impact of the earthquakes on the Nepali tourism industry would be a reduction of about 40 percent on average over the next 12 months, and a 20 percent reduction in the next 12 to 24 months (NPC, 2015b).

According to Post Disaster Needs Assessment (NPC, 2015b), the effects on the sector could be pointed out as follows:

- About NPR 16 billion worth of hotel properties were fully or partially damaged in the affected areas.

- Domestic airline operators reported total monthly income losses to the tune of NPR 400 million for the month following the earthquake.

- Tourist accommodations of different categories were either fully or partially damaged in the Langtang, Gorkha-Manaslu, Khumbu, Charikot, Kalinchok, Jiri, Dhanding, and the Rolwaling area. A few hotels in the Kathmandu Valley (including Nagarkot) were damaged extensively, while a majority of hotels developed minor cracks.

- A portion of key tourism monuments and heritage sites were turned to rubble.

- With respect to tourism infrastructure, about $150 \mathrm{~km}$ of trekking trails were significantly damaged. Another $200 \mathrm{~km}$ require maintenance and repair since access to rural areas is impeded.

- Tourist numbers expected to decline by about 90 percent between May and July 2015.

- A further implication concerned to the loss of jobs and revenue that the sector has provided to the country over the years.

A summary of damages and losses in the tourism sector is shown in Table 5 below. It is notable that apart from the trekking trails maintained by the government and other public organizations/projects, all the other sub-sectors are operated by the private sector; thus the impact of the earthquake has been greater upon the private sector. 
Table 5: Summary of Damages and Losses in Tourism Sector

\begin{tabular}{|l|r|r|r|r|r|}
\hline \multicolumn{1}{|c|}{ Subsector } & \multicolumn{2}{c|}{ Disaster Effects (NPR Million) } & \multicolumn{2}{c|}{ Share of Disaster Effects } \\
\hline & Damages & \multicolumn{1}{c|}{ Losses } & Total & Private & Public \\
\hline Hotels and others & 16,295 & - & 16,295 & 16,295 & - \\
\hline Homestays & 1,720 & 495 & 1,720 & 1,720 & - \\
\hline Eco-lodges & 415 & - & 415 & 415 & - \\
\hline Trekking trails & 426 & 5,711 & 6,137 & - & 6,137 \\
\hline Tour operators & 7 & 4,924 & 6,137 & - & - \\
\hline Tourism revenues & - & 47,013 & 47,013 & 47,013 & - \\
\hline Air transport revenues & - & 4,720 & 4,720 & 4,720 & - \\
\hline Restaurant revenues & - & 11 & 11 & 11 & $\mathbf{6 , 1 3 7}$ \\
\hline Total & $\mathbf{1 8 , 8 6 3}$ & $\mathbf{6 2 , 3 7 9}$ & $\mathbf{8 1 , 2 4 2}$ & $75, \mathbf{1 0 5}$ & - \\
\hline
\end{tabular}

Source: NPC, 2015b

\section{Tourism - Human Casualties}

Apart from the damages to physical properties and loss of business revenues induced by the great earthquake, there have been human casualties in the tourism sector too. As per the information available on the website of Nepal Disaster Risk Reduction portal (2015d), there have been 111 missing foreigners since the day of the earthquake. Most of them had been trekking in the Langtang region. The Government of Nepal has consolidated a list of 50 foreigners who had been injured during the crisis (Nepal Disaster Risk Reduction portal, 2015c). The list of 70 dead foreign visitors (Nepal Disaster Risk Reduction portal, 2015b) would certainly leave an unwanted but reminiscing memory for the tourism sector. The human casualties were mainly reported in the Langtang region with 18 dead. Hotel Budget Multiplex in Thamel had collapsed during the earthquake taking away life of at least 9 guests; while official record showed 7 foreigners dead in the Everest region.

\section{Tourism - Recovery Needs}

The earthquake is likely to have inflicted profound impact on the wider economy and mountain livelihoods unless a number of mitigating initiatives are pursued. These efforts need to target the global tourism market and convince potential visitors to come to Nepal, which will help affected tourism entrepreneurs in rural and urban areas (NPC, 2015b). The table shown below, Table 6, gives details on the recovery needs for the tourism sector as estimated by National Planning Commission (NPC) in the following two years. These figures cover the expenses required from demolition and clearing the debris at damaged sites to reconstruction activities. They also cover 
the amount of money required to help various tourism operators to revamp their businesses following the aftermath of the earthquake.

Table 6: Summary of Recovery Needs for Tourism sector

\begin{tabular}{|c|c|c|c|}
\hline \multirow{2}{*}{ Sub-sectors, activities } & \multicolumn{2}{|c|}{ Financial Year (NPR million) } & \multirow{2}{*}{$\begin{array}{c}\text { Total } \\
\text { (NPR million) }\end{array}$} \\
\hline & 2015-16 & 2016-17 & \\
\hline Recovery Activities & 10,866 & 5,209 & 16,075 \\
\hline Demolition and rubble removal & 3,018 & 755 & 3,773 \\
\hline Promotion campaign costs & 2,730 & 2,520 & 5,250 \\
\hline Loan rescheduling & 5,118 & 1,934 & 7,052 \\
\hline Reconstruction Activities & 18,571 & 4,064 & 22,635 \\
\hline Hotels & 15,643 & 3,911 & 19,553 \\
\hline Homestays & 2,064 & - & 2,064 \\
\hline Eco-Lodges in Conservation Areas & 498 & - & 498 \\
\hline Trekking trails & 358 & 153 & 511 \\
\hline Tour Operators Office & 8 & - & 8 \\
\hline Total & 29,437 & 9,273 & 38,710 \\
\hline
\end{tabular}

Source: NPC, 2015b

\section{Impact of the Earthquake on Hotels of Nepal}

According to the Ministry of Culture, Tourism and Civil Aviation (MOCTCA, 2015), 319,284 room nights out of the 523,453 room nights produced by the luxury hotels were sold in 2014. Five-star hotels recorded an average occupancy of 61 percent in 2014, up from 58.85 percent in 2013. There are 10 five-star properties in Nepal, eight in Kathmandu and two in Pokhara. The hotels recorded the highest occupancy rates of 86.33 percent and 73.02 percent in November and October respectively in 2014. Following the October-November season, hotels were busiest during March and April, recording an average occupancy of 72.77 percent and 70.62 percent, respectively. The lowest occupancy was recorded in January (49.78 percent), June (49.21 percent) and July (49.74 percent). Despite the growth in room occupancy last year, Nepal's hotels are foreseen to see a sharp fall in occupancy this year due to the earthquake (eKantipur.com, 2015).

As per news article posted on eKantipur.com by Sangam Prasain, Nepal could lose more than 300,000 tourists this year as a result of the April $25^{\text {th }}$ earthquake and its aftershocks which forced mass departure of tourists and prompted many to change their travel plans. Tourism Ministry spokesman Mr. Mohan Krishna Sapkota had 
informed the Parliamentary Development Committee that the country could lose up to 40 percent tourists - 320,000 - year-on-year basis. The country had received nearly 800,000 tourists in 2014. Based on the NPR 46 billion foreign exchange earnings from tourists that year, the country is likely to lose NPR 18 billion this year. The sharp drop in arrivals would also affect livelihood in the mountainous region, particularly among the people who depend on tourism income. Almost all the foreign sightseers had left the country immediately after the earthquake, affecting the business of hundreds of restaurants, hotels and retail stores (Prasain, 2015). Even domestic and international airlines had suffered huge losses following the crisis. The repercussions are estimated to continue at least until 2017. Sapkota had also told the lawmakers that tourist arrivals are projected to shrink 20 percent, both in 2016 and 2017.

Table 7: Preliminary statistics of damages in HAN member \& non member hotels

\begin{tabular}{|l|c|c|}
\hline \multicolumn{1}{|c|}{ District } & No. of Hotels (approx.) & Loss in NPR (approx.) \\
\hline Kathmandu & 300 & 3 billion \\
\hline Lalitpur & 50 & 1 billion \\
\hline Bhaktapur & 75 & 2 billion \\
\hline Kavre & 50 & 1 billion \\
\hline Sindupalchowk & 100 & 2 billion \\
\hline Dolakha & 90 & 2 billion \\
\hline Rasuwa & 100 & 2 billion \\
\hline Dhading & 100 & 2 billion \\
\hline Tanahun & 100 & 200 million \\
\hline Pokhara & 450 & No loss reported \\
\hline Chitwan & 200 & No loss reported \\
\hline Lumbini & 150 & No loss reported \\
\hline
\end{tabular}

Source: HAN, via email

As per preliminary survey conducted by Hotel Association Nepal (HAN) with the help of different agencies of Government of Nepal, Nepalese hotel sector has sustained losses amounting to more than NPR 15 billion approximately. Hotels in Kathmandu suffered the most with an estimate of NPR 3 billion damages and losses. Hotels in tourist destination such as Pokhara, Chitwan and Lumbini did not report any damages to the physical property due to the great earthquake. The amount of losses sustained by member and non-member hotels of HAN is presented in Table 7.

The intensity of capital investment in land, building and equipment are the causes that hotels have reported such huge amounts of damages and losses, as per Mr. Prabesh 
Aryal, Executive Director of HAN. He also stated that the increasing market prices, on-site surveys and detailed report by professional agencies would definitely lead to higher estimates than those stated in the table above.

The above figures are supported by another news article published on eKantipur.com which stated that profitability of hotels would plunge during the current fiscal year. The Soaltee Hotel Limited and Oriental Hotel Limited, which run Crowne Plaza and Radisson brand hotels respectively, posted a slowed revenue growth in the fiscal year 2013/14, largely due to the April 25 earthquake that severely affected business. The downturn was expected to continue in the following fiscal year as demand from business and leisure travelers had plunged since the disaster (eKantipur.com, 2015).

The article also reported that hoteliers are keeping their fingers crossed in the hope that the industry would see a revival in arrivals during the September-November peak tourist season. According to the fourth quarter report of the above two five-star hotels listed on the Nepal Stock Exchange (Nepse), Soaltee Hotel Limited had recorded a net profit of NPR 207.42 million in the fiscal year 2013/14, down 6.49 percent from previous fiscal year. Likewise, Oriental Hotel Limited had recorded a net profit of NPR 198.54 million, down 5.51 percent in comparison to the previous fiscal year.

According to Soaltee Hotel, negative travel advisories issued by a number of source markets, including the fastest growing Chinese market, immediately after the earthquake significantly affected tourist arrivals in the fourth quarter. Due to the dreadful event that prompted a mass departure of tourists, the hotel said that its revenues had dropped by 16 percent during the April-June period year-on-year basis. However, its earnings in operation rose by $3 \%$ to NPR 1.39 billion despite the earthquake. The hotel also mentioned that the government and concerned stakeholders in the hospitality industry had been devising various strategies to revive the industry in the aftermath of the earthquake which is expected to lead to a rebound to some extent. It also stated that it would continue its marketing and promotional strategy in various source markets, and would be diversifying and focusing on the meetings, incentives, conferences and exhibitions (MICE) segment to attract more visitors in the coming days.

Meanwhile, Oriental Hotel reported that its earnings in operation dropped by $2.57 \%$ to NPR 1.05 billion. It also mentioned that the hotel had taken some time to get back to full operations after the earthquake as it had conducted repair works; which in turn had affected the overall earnings. Oriental Hotel also stated that it had missed its occupancy targets as the tourist arrivals dropped to almost zero for a brief period after the great earthquake (eKantipur.com, 2015).

According to Ms Sinead O’Reilly, General Manager of Hyatt Regency Kathmandu - another five-star rated hotel in Kathmandu - in an interview published on tourismexecutives.com, the property did not sustain any structural damages, and received green sticker from the government to continue operating the hotel 
(Pradhananga, 2015). She also mentioned that the period after the earthquake had been slow in terms of business, with cancellations and visitors shortening their stay with the continuous aftershocks and rumors of even greater devastation. At being asked whether she felt safe staying in Nepal, she had replied that being a foreigner with two young daughters, she would not have stayed back here in Kathmandu if she would not have been confident enough about the safety of the hotel's physical structure. She also highlighted the fact that the hotel being operated by an international chain, there are safety and security procedures and plans in practice for various cases of emergencies. The staffs were able to implement the detailed procedures on April $25^{\text {th }}$, thus there was not much panic in the hotel that day.

The Everest Hotel, another five-star category hotel in New Baneshwor, Kathmandu survived the earthquake on April 25 ${ }^{\text {th }}, 2015$. However, according to Mr. Prahlad Kunwar, the General Manager of the hotel, the aftershock of May $12^{\text {th }}$ of 6.8 magnitude affected the physical structure with four columns damaged in the lobby area. Thus, it received 'red' sticker for structural damages and was subsequently shut down. Until then, it had $62 \%$ and 56\% occupancy in April and May respectively, compared to 60\% and 56\% during the same months in 2014. The hotel had estimated $82 \%$ occupancy for the month of June, which was all cancelled after the closure. There were no injuries to guests or staff; the safety procedures were followed by the employees as devised by the hotel. The hotel is estimated to come into operation in September 2016 after the completion of renovation works.

Hotel Shanker, a four-star category hotel located in Lazimpat, Kathmandu, sustained $10 \%$ damage to the physical property and suffered cancellation of $80 \%$ bookings after the earthquake, according to Ms Prina Shrestha, Executive Manager. She also mentioned that renovation had started and the hotel is currently operating with 40 guestrooms (out of 94).

Similarly, another famous and iconic property in Thamel area, Kathmandu Guest House, mentioned that the estimated cost of renovation after the earthquake would amount to NPR 30 million, with three months required to complete renovation works. It suffered a damage of $25 \%$ to the property, specifically in its old building that housed Heritage wing. Forty guestrooms, out of 139, have been on 'out of order' status since the disaster. The occupancy has remained on an average of $20 \%$ in the months of May to July 2015 with an expected increase to 60\% occupancy in the month of August.

Mr. Hemanta Pokhrel, Front Desk Executive at Hotel Yurkhang, Thamel mentioned that the hotel is running at an occupancy level of below 5\% after the earthquake, compared to above $50 \%$ during the same time period in 2014 . According to him, one guest also suffered a minor injury during the disaster. Minor renovation has already been completed in July, with the cost amounting to almost NPR 1 million.

Hotel Pacific at Jyatha, Kantipath suffered a major loss, as 50\% of its 32 rooms were damaged during the earthquake. After spending almost NPR 700 thousand, the 
hotel had 40\% occupancy in the month of August. In August 2014, the hotel was operating at $80 \%$ occupancy, as per Mr. Suman Shrestha, Managing Director of the hotel. This shows that it had lost $50 \%$ of the business after the earthquake. Likewise, in the months of May and June, only 2\% occupancy was recorded compared to $70 \%$ occupancy in the same period in 2014.

Another hospitality property, Kathmandu Beijing Hotel at Jyatha, Thamel, is almost without any guests since the earthquake. As per Mr. Sushil of the hotel, most of the hotel's clients are business people; thus the closure of border points with China had led to all the guests flying back to their hometown. However, he also stated that the guests have promised to come back as soon as everything comes back to normal.

Royal Singi Hotel (2015), located at Durbar Marg, Kathmandu had immediately closed down after the earthquake. The hotel had the following message posted on its website (http://royalsingi.com/)

"Dear Industry \& Business Partners, Friends, Families and Guests,

Our sincere gratitude for all your prayers, well wishes and support over the last few weeks since the closure of the hotel due to the unfortunate earthquakes. We would like to inform you that the repairs of the hotel are underway with strong pace and we are now pursuing to be open for operations as of Friday, September 25 th 2015.

We are confident that the nation is taking every measure to increase the safety of our citizens and guests. It gives us great pleasure to inform you that several countries have already either lifted their travel advisories or reduced the risk level. So for those of you who wish to visit Nepal again, thought of trekking one of the mountains in the Himalayan ranges or have us on your bucket list, please do visit our beautiful country where the hearts of the people are as strong and warmly welcoming as their determination to rise up as One Nation.

Namaste,

Royal Singi Hotel Management."

As of now, Royal Singi Hotel has reopened with more determination to provide better service with safer infrastructure.

Hotel Budget Multiplex in Thamel suffered a major devastation during the earthquake as the building had collapsed, killing all of the in house guests and staff. The Nepal Disaster Risk Reduction portal has mentioned that nine foreigners were dead who were staying in that hotel (2015b). The video of the building falling down could also be viewed on online video sharing website, youtube.com. 


\section{Situation of Thamel: The Tourist Hub}

Likewise, Research Management Cell of PATA Nepal Chapter prepared a report on 'Tourism in Thamel' after the earthquake, concentrating in Thamel, one of the famous tourist destinations within Kathmandu Valley. The report mentions that Thamel area was least affected by the quake in terms of physical and infrastructural damages, but the businesses in the area got affected economically. According to the survey, it was found that majority of the respondents (77.6 percent) stated 'financial loss due to loss of customers in shop/business' as the major impact of the earthquake. Similarly, 10.3 percent of the respondents had 'loss of guests', followed by 6.9 percent who had 'loss of relatives'. 4.3 percent stated there was 'loss of job in tourism industry', followed by 3.4 percent who suffered with 'injury’ (Dahal, 2015: 25).

Similarly, 58.7 percent of the total respondents had stated that they had lost ' 76 to 100 percent' in business (due to cancellations), 30.2 percent had 'less than 25 percent' cancellation, followed by 41.3 percent who had ' 26 to 50 percent' cancelled bookings (Dahal, 2015: 26).

Likewise, with regards to the impact of the EQ on respondent's organization finances, the survey reports that that most of the businesses suffered financially; while 63.1 percent of the respondents stated that the overall impact of the EQ on their revenues was 'very negative', followed by 32.0 percent who stated the impact to be 'negative', and lastly, 4.9 percent of the respondents stated 'neither negative nor positive' (Dahal, 2015: 32).

\section{Tourist Arrivals in Chitwan}

Table 8: Visitors in Chitwan

\begin{tabular}{|l|c|c|c|c|c|c|}
\hline & $\begin{array}{c}\text { Baishakh } \\
\text { (Apr/May) }\end{array}$ & $\begin{array}{c}\text { Jestha } \\
\text { (May/Jun) }\end{array}$ & $\begin{array}{c}\text { Ashadh } \\
\text { (Jun/Jul) }\end{array}$ & $\begin{array}{c}\text { Shrawan } \\
\text { (Jul/Aug) }\end{array}$ & $\begin{array}{c}\text { Bhadra } \\
\text { (Aug/Sep) })\end{array}$ & $\begin{array}{c}\text { Ashwin } \\
\text { (Sep/Oct) }\end{array}$ \\
\hline $\begin{array}{l}2071 / 72 \\
(2013 / 14)\end{array}$ & NA & NA & NA & NA & 10,661 & 20,957 \\
\hline $\begin{array}{l}2072 / 73 \\
(2014 / 15)\end{array}$ & 10,530 & 1,592 & 1,594 & 2,690 & 2,179 & 4,506 \\
\hline
\end{tabular}

Source: Poudel, 2015

Though hotels in Chitwan did not report any physical damages (Table 8), they did experience a downfall in number of visitors following the devastation of the great earthquake. According to an article published on Nagariknews.com by Ramesh Kumar Poudel (2015), the month of Baisakh (April/May), when the earthquake had occurred, saw 10,530 visitors coming to Chitwan; however it was followed by 1592, 1594, 2690, 2179 and 4506 tourists in the following five months of the Nepali calendar (May to September). On average, Mr. Poudel reported that Chitwan received 10,000 visitors every month in previous years. In 2014, Chitwan National Park had earned as much 
as NPR 240 million in entrance fees, from 178,000 visitors. The month of Ashwin, which saw 4,506 tourists in Chitwan this year, had accommodated 20,957 guests last year. This shows significant drop of $80 \%$ in number of visitors to Chitwan, which would lead to significant decrease in entry fee earnings of Chitwan National Park, as well as revenue from business of tourism operators in the region.

Maruni Sanctuary Lodge in Chitwan, operated by Kathmandu Guest House, mentioned that it is running at an occupancy level between 5 to $10 \%$ since the earthquake, though the natural disaster did not affect any of the buildings of the hotel. In 2014, the hotel had 50\% occupancy in the month of April, followed by $25 \%$ in the months of May, June and July. The hotel had operated at $90 \%$ occupancy in the month of August 2014.

In the same scenario, hotels in Pokhara also suffered with guests leaving before the slated departure dates, as well as declining number of tourist arrivals. Pokhara is one of main tourist destinations of Nepal. Ms Shirish Gurung, Managing Director at Hotel Didi, had been very optimistic with increasing trend of hotel bookings in her hotel, as well as other hotels of Pokhara in general, for the upcoming tourist season. Pokhara had not suffered any damages or losses caused by the earthquake, except that the tremors were felt by the residents; however the earthquake became the reason for reduced business revenue.

Similary, Hotel Lumbini Garden New Crystal in Lumbini has reported that the hotel is operating at an occupancy level below 5\% since April 2015 till date, with all of its 72 guestrooms in operation. As per Mr. Avyudaya Ratna Sthapit, Executive Director, $70 \%$ of the bookings were cancelled after the earthquake, even though there had been no damage reported in Lumbini, the birthplace of Lord Gautam Buddha.

The consequence of lesser tourists visiting Nepal has directly affected even those areas not devastated by the earthquake, such as Pokhara, Chitwan and Lumbini.

\section{Role of Hotel Association Nepal (HAN)}

Immediately after the great earthquake, HAN had arranged for Emergency Executive Committee Meeting. According to Mr. Prabesh Aryal, Executive Director of HAN, it was decided to form following three committees to be headed by Past Presidents.

- Tourist Help Desk for Committee under the Chairmanship of Mr. Yogendra Sakya that would collect tourist information (missing \& whereabouts) and hand over to the Government of Nepal

- Insurance, Banking, Finance Related Committee under the Chairmanship of Mr. Prakash Shrestha

- Hotel Infrastructure and Employee and Families Loss Assessment Committee under the Chairmanship of Mr. Prasidha B. Panday 
Mr. Aryal also informed that 'HAN Earthquake Relief Fund' was established under the Chairmanship of Mr. Shyam S.L. Kakshapati and it was requested to all HAN member hotels and institutions to contribute to the fund. The money collected was handed over to Prime Minister's Disaster Relief Fund later. The Committee also distributed biscuits and drinking water to the tourists at Tribhuvan International Airport (TIA). It also distributed relief materials like tents and blankets in Nagarkot to 250 earthquake victim families. Tents, food items and medicines were also handed over to 600 earthquake victim families in Boch VDC of Dolakha District.

'Hotel Infrastructure and Employee and Families Loss Assessment Committee's objectives were to be involved in endeavors to support and expedite government's rescue mission to the victims of devastating earthquake. The committee had immediately started collecting the data of human and property loss in member hotels. The Committee had decided to provide national and international experts for assessment of the damages after receiving details from HAN Members.

Similarly, 'Insurance, Banking and Finance Related Committee' was designated to coordinate hotels with the financial institutions like banks and insurance companies. It had collected information about HAN members' tentative loss by the earthquake, the respective names of their insurance companies and financial institutions. The Committee also collected grievances related to banking and insurance issues from member hotels and met with Chairman of Insurance Board Nepal, Chief Secretary of the Government of Nepal, Governor of Nepal Rastra Bank and officials of Bankers Association Nepal; and brief them about the losses in the hotel industry and requested them to initiate relief packages for the revival of tourism industry. The Committee also facilitated an interaction program between house owners/landlord and hotels operators on rental concession for some time considering the meager tourist arrival in the post earthquake situation.

\section{HAN and National Society for Earthquake Technology (NSET)}

From the disaster risk management perspectives, private sector entities have twofold role in building resilience in their businesses and contributing as a part of corporate social responsibility in enhancing community resilience (NSET, 2014a). In this regard, HAN signed a Memorandum of Understanding (MOU) with NSET to work together for disaster resiliency of hotel industry in Nepal (NSET, 2014a \& 2014b).

Mr. B.K Shrestha, President of HAN and Dr. Amod Mani Dixit, Executive Director of NSET had signed the MOU. Mr. Shrestha had appreciated the initiation taken by NSET for collaborating with HAN, and for its active involvement towards disaster risk reduction of hotel industry in Nepal. He had also briefed that HAN would extend its cooperation in every aspect of Disaster Risk Reduction (DRR) and would like to work with Government of Nepal, NSET and all concerned stakeholders on making the hotel industry disaster resilient and leave a positive message to the tourists coming from around the world. 
Dr. Amod Mani Dixit also highlighted the role of private sector in earthquake risk management, and the need for the private sector to make their family and their business safer through the development and implementation of Business Continuity Plan. He had pointed out the importance of the hotel industry and its contribution to the national economy - thus the necessity of this industry on being safer against any kind of disaster. He had rolled out plans to work with HAN in future to implement Hotel Sector Earthquake Safety Program with the objective of making the hotel sector well-prepared and that, all stakeholders are able to continue their business activities uninterrupted even after a disaster.

A half-day interactive presentation session program was also jointly organized by HAN and NSET under Public Private Partnership for Earthquake Risk Management (3PERM) Program to enhance the disaster resiliency of Nepal's tourism industry, especially the hotel sector - which is considered to be a major stakeholder of national economy and, to have had the highest local private sector investment in Nepal with the recorded investment of around NPR 100 billion (NSET, 2014a).

Following such agreements with HAN, NSET had conducted specific training courses such as Light Search and Rescue (LSAR), Basic Emergency Medical Response (BEMR), Damage Assessment Training (DAT) and Non-Structural Mitigation (NSM) from October $14^{\text {th }}$ to $17^{\text {th }}, 2014$ (NSET, 2014c). A total of 25 participants representing different hotels in Kathmandu had participated in the program.

Similarly, HAN Kanchanpur Chapter had also organized a half-day discourse on November $2^{\text {nd }}, 2014$ which focused on 'Earthquake Risk of Nepal \& Need for Preparedness of Hotel Industry'. It was requested to all the existing hotel and guest house owners to act immediately on necessary disaster preparedness of the hotel sector (NSET, 2014d).

\section{Disaster Preparedness}

Every year, Nepal celebrates 'Earthquake Safety Day' on Magh $2^{\text {nd }}$ (mid-January), the day of the Great Earthquake in 1990 BS (1934 AD). That earthquake had produced strong shaking in Kathmandu Valley and, destroyed 20 percent and damaged 40 percent of the valley's building stock. Many of the temples in Bhaktapur were also destroyed (NSET \& GHI, 1998: 8).

NSET \& GHI (1998) had published a report entitled 'The Kathmandu Valley Earthquake Risk Management Action Plan' which had a simple loss estimation study conducted for Kathmandu Valley. It had revealed that if the 1934AD earthquake shaking were to occur in modern day Kathmandu Valley, it was quite reasonable to assume that 60 percent of all buildings in the valley would likely be damaged heavily, many beyond repair; almost half the bridges in the valley would be impassable; $10 \%$ or paved roads would have moderate damage; many narrow streets would have been blocked by debris from damaged buildings; the only international airport, Tribhuvan 
International Airport, would have been isolated from the rest of the valley; $95 \%$ of water pipes and $50 \%$ of other water system components would have been damaged seriously; almost $40 \%$ electric lines would likely be damaged and all these services would require at least one year to come into operation after repair.

Likewise, there would have been an estimated 22,000 deaths and 25,000 injuries requiring hospitalization; with increased estimated figures of 40,000 and 95,000 casualties respectively. An additional 600,000 to 900,000 residents of Kathmandu Valley were expected to be left homeless by the earthquake, due to either damaged buildings or the fear of being in their homes. And there would have been a major shortage of space for medical treatment in the valley (NSET \& GHI, 1998: 9-10).

However, knowing the above data being published in 1998 - almost 20 years beforehand - deaths of almost nine thousand people and damages to 14 districts of the country showed that Nepalese were not fully prepared for such a natural calamity. As mentioned previously, the combination of natural forces and human settlements are the elements of natural disasters. Thus, such settlements and the inhabitants suffer the most during such crisis.

In terms of disaster preparedness, Ms O'Reilly had mentioned that Hyatt Regency Kathmandu was proactive about any case of emergency with detailed safety procedures and contingency plans. With ample space available for shelter, and the tennis court designated as the assembly area, the hotel had also kept containers with emergency essentials at different locations within the hotel premises. She also highlighted about the team effort of the staff for practice of safety procedures during training sessions and implementation of the same on the actual day of the disaster proved to be successful to avoid any kind of unwanted event. She also stated that the guests and staff were all safe as a result of such safety procedures being in place and the ability of the staff to follow them at the time of disaster (Pradhananga, 2015).

Mr Kunwar had also specifically pointed out the safety procedures devised by Everest Hotel were sufficient and up-to-date for incidents of large magnitude, just like the earthquake of April $25^{\text {th }}, 2015$. He also considers that it was the reason for none of the guests or staff being injured on that particular day. Ms Shrestha admitted that the safety procedure at Hotel Shanker were not enough to cover the incidents during and after the earthquake. She mentioned that more detailed safety procedures are being discussed and planned to be in practice soon at her hotel. Other hotels had raised the necessity for more training and practice of the safety procedures, so that the employees are better prepared for such natural calamities in the future.

Similarly, the survey conducted by PATA Nepal showed that only 6.9 percent of the respondents from Thamel were prepared for such quakes. On the other hand, 52 percent of the respondents were 'unprepared' for such quakes and aftershocks, followed by 30.4 percent who were 'very unprepared'. From the research, it was evident that 
only 2.9 percent were 'very prepared' of such quakes. Similarly, 7.8 percent were 'neither prepared nor unprepared' for such situations. 12.1 percent did not respond to this question (Dahal, 2015: 28).

Crucial factors in organizations' survival in a time of disaster are effective and efficient preparation in advance of the disaster; a speedy response to the situation that occurs; and strategic recovery following the disaster. Today, as never before in the history of the hospitality industry, all industry organizations have an indisputable responsibility for the safety, health and welfare of their guests, as well as their employees (McCool, 2012). Thus, it is imperative that hospitality businesses are proactive in their approach to crisis and disaster management. Such organizations have written disaster management strategies and plans, along with a well-trained staff and persons in leadership roles who are knowledgeable about effective disaster management. While the importance of such preparedness is recognized throughout the hospitality industry, the need for guidance on the preparation and effective implementation of disaster management plans still remains.

In a study conducted by UNISDR, PATA and GIDRM (2015: 23) it was found that risk management strategies in small hotels tend to be designed based on the experience of the upper management. It was also mentioned by some small hotel representatives that they do not have the support of a 'head office' to guide them in the direction of best practices and to provide specialist advice. Whereas, those interviewed during the study had noted that chain hotels have thorough systems, processes and requirements in place for disaster risk management that are audited on a regular basis. It was also found that corporate support was provided to chain hotels, which included assisting hotels during disasters, crisis management software, provision of experts when necessary and the standards, policies and protocols developed on behalf of hotels ( $\mathrm{p}$. 24).

The same report also identified the importance of working alongside the government agencies that play a role in disaster risk management if any disaster risk reduction measures are to make a difference. This is due to the importance of these agencies in addressing risks such as road access, planting trees to prevent landslides, early warning systems, in communicating changing risks and in response (p. 24). The importance of training to ensure that staff are prepared for disasters and are confident of what to do in an emergency situation is also emphasized in the study (p. 25).

\section{Conclusion}

Dramatic fluctuations in tourist arrivals after the great earthquake have made Nepal's tourism sector vulnerable to uncertainty in many ways. Nine in ten planned foreign arrivals were cancelled in the aftermath of the quakes which occurred during the first of the two major seasons of the year. The main earthquake and prolonged aftershocks caused damage to seven out of 10 World Heritage sites in the Kathmandu 
Valley and affected popular trekking routes. Destroyed tourism-related supply of services and decreased tourist spending could lead to a loss of NPR 62 billion over the next two years. Within the same scenario, Nepalese hotels have suffered a lot too with NPR 16,295 million estimated in damages and losses. The consequence of lesser tourists visiting Nepal has directly affected not only hotels in Kathmandu, but even those hotels that are located in areas not devastated by the earthquake too, such as Pokhara, Chitwan and Lumbini. There has been a significant decrease in occupancy level of the hotels as compared to same timeframe of previous years.

A hotel collapsed in a well-known tourist area in Kathmandu, while a five-star category rated hotel had to be shut down due to damage to its physical structure. Some have resumed operations after repair and renovation; however, most of the hotels are yet to achieve the targeted occupancy level on par with those of yesteryears. Nepalese hotels still lack preparedness in terms of disaster management and risk reduction. Learning from the experiences of the earthquake and post-earthquake events, they should be able to develop better safety procedures; with initiative taken by hotel owners and/or management, and involvement of the staff. Government of Nepal and Hotel Association Nepal should coordinate the rebuilding process of the hotel industry along with the assistance of various stakeholders of tourism sector.

Globally, visitors from emerging economies represented a $46 \%$ share of these international arrivals that showed growth and increased opportunities for travel from those in these new markets. This should be a source of hope and encouragement for Nepalese hotels. However, as rightly mentioned by Kachali et al (2012), post-disaster recovery is a complex economical, political, social and physical process. Recovery is not just about rebuilding infrastructure, it should also be used to plan for future economic growth. Nepal's hotel sector should materialize the goals to achieve more visitors as soon as possible along with better plans and strategy for disaster preparedness.

\section{Acknowledgement}

I would like to thank Prof. Dr. Ramesh Raj Kunwar for providing me this opportunity and his continuous guidance; MIMT faculty members for their support; my family for believing in me; and lastly, the management and colleagues at IST for their cooperation.

\section{References}

AlBattat, A. R. and Som, A. P. M. (2013). Emergency preparedness for disasters and crises in the hotel industry. SAGE Open.

(2014). Disaster preparedness of hotel industry abroad: a comparative analysis. Retrieved on September 10, 2015 from http://dx.doi.org/10.1051/ shsconf/20141201012

(2015). Emergency preparedness of the hotel industry: the case of Jordan. Advances in Environmental Biology 9(3), 19-22. 
Anderson, M. B. (1990). Analyzing the costs and benefits of natural disaster responses in the context of development. Environment Working Paper 29. Washington, D.C.: World Bank.

Beattie, M. A. (1992). The effect of natural disasters on tourism - a study of Mount Saint Helens and Yellowstone National Park. Rochester Institute of Technology, New York. Thesis. Retrieved on September 21, 2015 from http://scholarworks.rit.edu/ theses/7428

Benson, C. and Clay, E. J. (2003). Disasters, vulnerability and global economy. A. Kreimer, M. Arnold, \& A. Carlin (Eds.), Building Safer Cities: Future of Disaster Risk (3), 3-32.

(2004). Understanding the economic and financial impacts of natural disasters. Disaster Risk Management Series (4). Washington, D.C.: World Bank.

Boarnet, M. G. (1997). Business losses, transportation damage and the Northridge earthquake. Journal of Planning Literature (11), 476-486.

Bryman, A. and Bell, E. (2011). Business research methods. New Delhi: Oxford

Buhalis, D. and Costa, C. (2006). Tourism management dynamics. UK: Elsevier Butterworth-Heinemann.

CBS (Central Bureau of Statistics). (2010). Statistical Pocket Book of Nepal 2009. Kathmandu: CBS.

(2015). Statistical Pocket Book of Nepal 2014. Kathmandu: CBS.

Cochrane, H. (2004). Economic loss: Myth and measurement. Disaster Prevention and Management, 13(4), 290-296.

Dahal, R. (2015, August). A report on 'Tourism in Thamel'. Kathmandu: PATA Nepal Chapter, Research Management Cell.

Edgell, Sr., D. L. (1990). International Tourism Policy. New York: Van Nostrand Reinhold. eKantipur.com. (2015, August 20). Hotel profits plunge as quake hits occupancy. The Kathmandu Post. Retrieved on October 20, 2015, from http://kathmandupost. ekantipur.com/news/2015-08-20/hotel-profits-plunge-as-quake-hits-occupancy.html

Frazier, K. (1979). The violent face of nature - severe phenomena and natural disasters. New York: William Morrow \& Co.

Gruman, J. A., Chhinzer, N., and Smith, G. W. (2011). An exploratory study of the level of disaster preparedness in the Canadian hospitality industry. International Journal of Hospitality \& Tourism Administration, 12(1), 43-59

Gunn, C. A. (2002). Tourism planning - basics, concepts, cases. New York: Routledge

HAN (Hotel Association Nepal). (2015). Monthly e-newsletter of Hotel Association Nepal, (May/June). Kathmandu: HAN. 
Kachali, H., Stevenson, J. R., Whitman, Z., Seville, E., Vargo, J. and Wilson, T. (2012). Organisational resilience and recovery for canterbury organisations after the 4 September 2010 Earthquake. Australasian Journal of Disaster and Trauma Studies (1). Retrieved on September 20, 2015 from http://trauma.massey.ac.nz/issues/20121/AJDTS_2012-1_Kachali.pdf

Kroll, C. A., Landis, J. D., Shen, Q. and Stryker, S. (1991). Economic impacts of the Loma Prieta Earthquake: a focus on small business. Working Paper No. $91-187$. Berkley, CA: University of California, Transportation Center and the Center for Real Estate and Economics. Retrieved on September 20, 2015 from https://escholarship.org/uc/item/05f3382m

Kunwar, R. R. (2010). Tourists and Tourism: Science and Industry Interface. Kathmandu: Ganga Sen.

..(2012). Safety and security in tourism: a study of crisis and disaster management. Journal of Tourism and Hospitality Education, (2), 58-83.

(2015). Tourism and Natural Disaster: A Study of Nepal's Earthquake - 2015. Voice of Himalaya 4(1), 19-37. Kathmandu: Mountain Academy Nepal.

Kunwar, R. R. and Limbu, B. (2015). Tourism and Earthquake: A Case Study of Nepal and Turkey. Building Better Tourism with Renewed Strength, XXth NATTA Convention,16-31. Kathmandu: Nepal Association of Tour \& Travel Agents (NATTA).

McCool, B. N. (2012). The need to be prepared: Disaster management in the hospitality industry. Journal of Business \& Hotel Management, 1(2). Retrieved on July 12, 2015 from http://dx.doi.org/10.4172/2324-9129.1000101

Ministry of Finance (MoF). (2015, July). Economic survey fiscal year 2014/15. Kathmandu: MoF.

MOCTCA (Ministry of Culture, Tourism and Civil Aviation). (2015, July). Nepal Tourism Statistics 2014. Kathmandu: MOCTCA.

MoHA (Ministry of Home Affairs) and DPNet-Nepal (Disaster Preparedness Network - Nepal). (2013). Nepal disaster report 2013 - focus on participation and inclusion. Kathmandu: MoHA \& DPNet-Nepal.

MoHA (Ministry of Home Affairs). (2015). Nepal earthquake 2072: situation update as of 11th may 2015. Retrieved on September 20, 2015 from http://drrportal.gov.np/ uploads/document/14.pdf

Munich Re. (1999). A year, a century, and a millennium of natural catastrophes are all nearing their end. Press release of December 20, 1999. Munich: Munich Re.

National Research Council. (1999). The impacts of natural disasters - a framework for loss estimation. Washington, D.C.: National Academy Press. 
Nepal Disaster Risk Reduction Portal, Government of Nepal. (2015a). Risk profile of Nepal. Retrieved on September 20, 2015 from http://drrportal.gov.np/risk-profile-of-nepal

Nepal Disaster Risk Reduction Portal, Government of Nepal. (2015b) List of dead foreigners. Retrieved on September 20, 2015 from http://drrportal.gov.np/uploads/ notice/39.pdf

Nepal Disaster Risk Reduction Portal, Government of Nepal. (2015c). List of injured foreigners Retrieved on September 20, 2015 from http://drrportal.gov.np/uploads/ notice/40.pdf

Nepal Disaster Risk Reduction Portal, Government of Nepal. (2015d) List of missing foreigners Retrieved on September 20, 2015 from http://drrportal.gov.np/uploads/ notice/41.pdf

NPC (National Planning Commission). (2015a). Nepal earthquake 2015 - post disaster needs assessment - executive summary. Kathmandu: NPC.

.. (2015b). Nepal earthquake 2015 - post disaster needs assessment volume a - key findings. Kathmandu: NPC.

(2015c). Nepal earthquake 2015 - post disaster needs assessment volume $b$ - sector reports. Kathmandu: NPC.

NSET (National Society for Earthquake Technology, Nepal) and GHI (GeoHazards International, USA). (1998). The Kathmandu valley earthquake risk management action plan. Kathmandu: NSET \& GHI

NSET (National Society for Earthquake Technology, Nepal). (2014a. August). Hotel industry to enhance disaster resiliency. Retrieved on September 20, 2015 from http://nset.org.np/nset2012/index.php/event/eventdetail/eventid-190

.. (2014b, August). NSET and HAN sign MOU. Retrieved on September 20, 2015 from http://nset.org.np/ nset2012/index.php/event/eventdetail/eventid-194

(2014c, October). Emergency response training to hotel sector stakeholders. Retrieved on September 20, 2015 from http://www.nset.org.np/ nset2012/index.php/event/eventdetail/eventid-207

. (2014d, November). HAN-Kanchanpur Chapter to enhance disaster resiliency of hotel sector business. Retrieved on September 20, 2015 from http://www.nset.org.np/nset2012/index.php/ event/eventdetail/eventid-210

Pacific Asia Travel Association (PATA). (2015). The PATA Nepal tourism rapid recovery task force - report \& recommendations. Bangkok: PATA.

Pender, L. and Sharpley, R. (2005). The management of tourism. London: Sage Publications.

Poudel, R. K. (2015, October 29). Nikunja ghumne paryatak teen mahinama pani 10 hajaar pugenan. Naragarik Nepali National Daily. Retrieved on October 30, 2015 from http://nagariknews.com/economy/story/47783.html 
Pradhananga, P. (2015, June 22). Interview with Sinead O'Reilly, GM of Hyatt Regency Kathmandu. Retrieved on September 20, 2015 from http://www.tourismexecutives.com /51592/interview-sinead-o-reilly-gm-hyatt-regency-kathmandu

Prasain, S. (2015, June 17). Nepal could lose 'over 300k' visitors this year. The Kathmandu Post. Retrieved on September 20, 2015 from http://kathmandupost.ekantipur.com/ printedition/news/2015-06-16/nepal-could-lose-over-300k-visitors-this-year.html

Racheria, P. and Hu, C. (2009). A framework for knowledge-based management in the hospitality and tourism industry. Cornell Hospitality Quarterly 50, 561-577

Richardson, S., March, R., Lewis, J., and Radel, K. (2012). Analysing the impact of the 2011 natural disasters on the Central Queensland tourism industry. TEAM Journal of Hospitality and Tourism, 9(1), 1-14. Retrieved on September 20, 2015 from https://teamjournalht.files.wordpress.com/2013/05/team-edsprvrev-p1-14.pdf

Rose, A. and Lim, D. (2002). Business interruption losses from natural hazards conceptual and methodological issues in the case of the Northridge Earthquake. Global Environmental Change Part B: Environmental Hazards, 4(1), 1-14.

Royal Singi Hotel. (2015). Website message retrieved on September 10, 2015 from http://www.royalsingi.com/

Sato, A. (2012). Impact of the Great East Japan Earthquake on hotel industry in Pacific Tohoku Prefectures. Progress of Theoretical Physics Supplement No. 194. Retrieved on July 7, 2015 from http://ptps.oxfordjournals.org/content/194/165.full.pdf

Soraghan, E. (2009) Management and disaster. University of Nevada, Las Vegas (UNLV) Theses/Dissertations/Professional Papers/Capstones. Paper 638

Swarbrooke, J. (1999). Sustainable tourism management. UK: CABI Publishing.

Tierney, K. and Webb, G. R. (2007). Business vulnerability to earthquakes and other disasters. C. M. Rodrigue \& E. Rovai (eds.). Earthquakes, 994-1031. London: Routledge.

UNISDR (The United Nations Office for Disaster Risk Reduction), PATA (Pacific Asia Travel Association) \& GIDRM (Global Initiative on Disaster Risk Management). (2015, July). Developing strategies to strengthen the resilience of hotels to disasters - a scoping study to guide the development of the hotel resilient initiative. Bangkok: UNISDR, PATA \& GIDRM.

WTTC (World Travel and Tourism Council). (2015). Travel and tourism economic impact 2015 - Nepal. Retrieved on October 28, 2015 from http://www.wttc.org//media/files/reports/economic\%20impact\%20research/countries\%202015/nepal 2015.pdf 